\title{
Quantifying the Preference of Islamic Banking in Pakistan
}

\author{
Sadaf Mustafa ${ }^{1}$, Abdur Rafay ${ }^{2}$, Syed Shoeb Ahmed ${ }^{3}$ \\ ${ }^{1}$ Department of Commerce, University of Karachi, Karachi, Pakistan \\ Email: ameerfatima48@yahoo.com \\ ${ }^{2}$ Department of Commerce, University of Karachi, Karachi, Pakistan \\ ${ }^{3}$ Department of Public Administration, University of Karachi, Karachi, Pakistan \\ Email: s.ahmedku@gmail.com
}

\begin{abstract}
The core reason of this research is to ascertain the factors behind preference of Islamic banking in Pakistan. The nature of this study is quantitative and the essential objective of this study is to find out that why the preference of Islamic banks in Pakistan has increased over the time. The research design used to accomplish this result is correlation research design and the tool used to conduct this research is questionnaire. Out of the 100 respondents the full $100 \%$ replied. The ratio of female respondents to male respondents was relatively very low. The questionnaires were distributed to those individuals who were employed and had a bank account. Questionnaire responses were given on a likert scale, with response 1 as strongly disagree to response 5 for strongly disagree. The results were analyzed using basic statistics, including measures of central tendency. The findings of this research indicate various factors that account for preference of Islamic banking. The factors include reputation, Shariah compliance, customer satisfaction and service quality. This study will be supportive to those individuals who prefer opening their account in Islamic banks. By this study, the individuals can get a lot of help that what are the major factors that are considered by different individuals.
\end{abstract}

Keywords- Islamic banking, shariah compliance, profitability of Islamic banking sector.

\section{INTRODUCTION}

Islamic banking started to come into appearance in the 1970's. From that period of time it has been on the rise and is constantly emerging internationally [1]. At the moment Islamic banking industry stands at the benchmark of 1 trillion US dollars year end 2008 [2]. It is an educated guess of the international credit rating agency that the Islamic banks have the potential to expand to 4.0 trillion US dollars. Countries like UK, France, China, Singapore and most of the different countries have developed supervisory body to smooth the progress of
Islamic banking. The international expansion of the Islamic banking industry including Pakistan has accelerated since 2002 [3].

In the current scenario Islamic banking is growing at a very rapid pace, more and more people are preferring Islamic banking and are paying more attention to the profit and loss sharing institutions [4]. Islamic banking has taken huge steps in the elimination of Riba banking that is interest banking and has encouraged many individuals on doing interest free banking.

The objective of this study is to examine about the fact that why conventional financial institutions that have been operating for a very long period of time almost 3 centuries with a very strong base have begun to plummet sharply for over some decades and at the same time Islamic banking is making its expansions internationally specially in the Muslim countries, with rapid growth rate. The upright expansion of Islamic banking in a very short period has astonished everyone specially the western professionals and analysts. A huge exploration is being done on the Islamic finance and many people are doing research on Islamic finance and banking. A total of 970 books were published in a short time. In addition, thousands of research articles have also been devoted to research on Islamic finance, studying topics ranging from differences in conventional versus Islamic banking to state regulations and control on Islamic financial institutions. This little information about the researches and books that are being published shows the increasing curiosity of the researchers in the Islamic finance.

Islamic banking preference has increased rapidly over the past three decades. Islamic banking first was only operating in the Muslim nations but now it has gained international recognition. It is spreading its operations in the western countries also and is achieving its objectives. Individuals all over the world prefer Islamic banks. This research is carried out to find out the factors that affect the individual's perception of preference, this study is only limited to Pakistan scenario. 


\section{RESEARCH OBJECTIVE}

This research was conducted to discover the preference that people are giving to Islamic banks in Pakistan over traditional financial institutions, or commercial banks. Specific objectives of this research are given below:

- The level of preferences people give to Islamic banks over conventional banks

- The level of awareness people have in Islamic banking methods over the conventional banking methods

- Measures the profitability of the Islamic banks over conventional banks

- Measures the satisfaction of customers and the service that is provided to them by the Islamic financial Institutions over the conventional financial institutions

- Measure that does the reputation of the institution effects it in a positive or negative manner

- The level of Shariah compliance of the product that is offered by Islamic banks.

\section{RESEARCH HYPOTHESES}

$\mathrm{H}_{1}$ : Preferences of customers effect banks customer base

$\mathrm{H}_{2}$ : Profitability of a bank increases customer retention rate

$\mathrm{H}_{3}$ : Awareness about Islamic banking would retain new customers

$\mathrm{H}_{4}$ : Shariah compliance retains new customers

$\mathrm{H}_{5}$ : Employee-customer positive interaction and service quality increases customer loyalty

$\mathrm{H}_{6}$ : Reputation of a bank will affect a customer's psychology

\section{LITERATURE REVIEW}

Islamic banking activities are not restricted to Arab soil or Muslim nations but it is expanding its operation around the globe [5]. One motive is the growing trend of going beyond the national boundaries and bringing together Muslims into a political and economic entity that could change the model of the world trade. Since Muslims are vision to follow Islamic traditions, there is a trend to develop an Islamic economic system in every Muslim nation and to restore Shariah law as the basic source for legislation. [6] states that almost 100 percent of the Muslim population in Malaysia was aware informed of the Islamic banking system, the main sources behind this information were newspapers, magazines, and media and radio.

Market analysis based on the total assets that were made public in the financial statement gave the evidence that conventional banks are dominant in the GCC countries. But over the time conventional banks market share is decreasing over Islamic banks [7]. As the data suggest the total assets of conventional banks were $87.91 \%$ in the year 2000, which has decreased to $85.84 \%$ in 2005 with $40.64 \%$ growth rate [7]. While the total assets of Islamic banks increased by $2.07 \%$ which were from $12.09 \%$ in 2000 to $14.16 \%$ in 2005 and had a growth rate of $50.53 \%$. the data indicates that conventional banks dominated the GCC countries in the past but as the time is passing by and keeping in view the current data statistics Islamic banks are growing at a much rapid pace that of conventional banks [4].

[8] stated that to guarantee the Islamic banking sectors long-term growth and success we will have to overcome the lack of knowledge people have about Islamic banking. We will have to select the places that we target and make them aware of the Islamic banking concepts by taking these positive steps and by entering more markets of friendly Islamic banking products would enter in the competitiveness with conventional products. By helping and making it easy for them to grasp the products that are being offered by the Islamic banks will help customers in making better choices [8]. The consumers have additional benefits of insuring that the services that are being provided either by conventional or by Islamic bank, do they give proportionate value to the customers. This is one of the most important part of a growing financial services sector.

Masruki, Ibrahim, Osman and Wahab stated that if the profitability of Islamic bank is compared with conventional banks, the end result they came up with was astonishing, as conventional banks are more profitable than Islamic banks [6]. But Islamic banks have a much effective liquidity rate than of conventional banks. Conventional banks have a higher profitability rate because of the increased net financing and they have better quality of assets. The liquidity ratio that Islamic banks have could be because of the financings done with a limitation that is the financing must be Shariah compliant.

Abdul Hafeez Qureshi, Zile Hussain and Kashif Ur Rehman stated that customers in Pakistan like relieve and luxury to perform a transaction with Islamic bank or conventional bank. Religions point of view of the customers is important but only reliability of religious perception cannot accomplish the need of the customer [9]. Many factors play an important role in the process to attract customers toward them let it be a conventional or an Islamic institution. Most banking customers would not want to continue transactions with banks, until both the banks offer essential services and benefits according to the demand of the consumers.

Beng Soon Chong \& Ming-Hua Liu stated that in their paper they made an attempt to find out that whether Islamic banking has some distinction from conventional banking. They identified a unique feature that 
distinguishes between the Islamic and conventional banking is the PLS paradigm [10]. Still they discovered that Islamic banking is not very much unique of conventional banking with respect to the PLS paradigm. On the asset side of the balance sheet they found out that an insignificant portion is based on the PLS paradigm. In Malaysia non PLS financings are still being done by the Islamic bank that is admissible by the Shariah law, but ignore the spirit of usury prohibition.

Abdul Ghaffar Awan stated in research that expansion of Islamic banks in comparison with some specific conventional banks during the year 2006-2008 explain that Islamic banks have had constant expansion right from the time they entered into the market [5]. As we have seen rapid expansion in the area of Is lamic banking, the total assets of the banks have also increased rapidly.

Beck (2010) states that Is lamic banking is making its path in the western nations and in expanding its network to many new western countries. Islamic banking is a tendency that is most likely will carry on as oil exporting nations keep on building their wealth, GCC and south East Asian markets expand in the future and the companies on western side compete with one another to attract international investors [2]. However, even though Islamic banking is expanding at a very rapid pace in the near past, most of the administrative authorities are unknown by the methods by which Islamic banking is being injected into a conventional system. As Islamic institutions keeps on expanding and prospering, the management or the supervising institutions will have to be very confident that these new institutions get fully integrated with current financial system. This method of integration will not only allow the Islamic institutions to function but will also provide a complete statutory framework and will help in developing a helpful financial network.

Muhammad Hanif (2010) stated that the Islamic institutions that are trying to compete with the conventional banks are too close to them in products that are offered and in total cost to consumers. This closeness of cost effects the consumer's perception negatively related to functioning of Islamic banks [11]. Islamic finance is based on the system of justice and equity it is not based on the principal of capitalism, it should be operated by keeping this function in mind. It has its own system based on equity and risk sharing which create a different economic system. If Islamic institutions want to benefit their consumer's like the conventional institutions and keep on with the conventional banking system then surely, they will have to leave some certain principles and practices, that would not make everyone glad. The essence of Is lamic banking is sharing, sharing of risk and reward by both the parties involved the bank and the consumer.
[12] stated in their study that consumers from both sides of the financial institutions let it be convention or Is lamic, were satisfied by the services being provided to them. However, the consumers of the conventional banking services were more satisfied by the consumers of the Islamic banking services. The examination of the data gave a clear result that the factors that made conventional consumers more satisfied than Islamic consumers were economic benefits, financial position of the bank, interest on deposit, strong global image and network reputation.

Muhammad Shehzad Moin stated that the result of study show that conventional banks are more profitable and are largely different in two different ratios the ROE and the PER [1]. The study shows that conventional banks don't largely differ from Islamic banks in the ROA ratio. Additional examination of the result showed that Islamic banks are catching up with the conventional banks and could outperform conventional banks in the mere future. In a different study of comparing conventional banks with the Islamic banks, the MBL has outrun many of the conventional banks.

[13] stated that Islamic banking is one of the fastest expanding sectors of the financial services sector. It has a large contribution in the global financial market and it has become too big to be ignored by the others. In simple words conventional banking is done on debt-based principle and the burden on risk is transferred to others while Islamic banking is purely done on Asset based principle and the risk is shared between the parties. The characteristics of Islamic banks make them much more related to the real economy.

Munawar Iqbal stated in his study that analysis of the functioning of Islamic banks through some major ratios gave pleasing results. Islamic banks are well capitalized and they are using their resources is much better way, Is lamic banks aren't cost effective in their operations. The profitability ratios of Islamic banks can be in fortunate comparis on with the international standards. In should be kept in mind that depositor of the Islamic banks demands a higher rate of return because they are sharing more risk than that of conventional banks [14].

\section{ANALYSIS OF DEPENDENT AND INDEPENDENT VARIABLES}

Islamic banking preference has increased rapidly over the past three decades. Islamic banking first was only operating in the Muslim nations but now it has gained international recognition. It is spreading its operations in the western countries also and is achieving its objectives. Individuals all over the world prefer Islamic banks. This research is carried out to find out the factors that affect the individual's perception of preference, this study is only limited to Pakistan scenario. The framework below 
shows the dependent and independent variables to be tested.

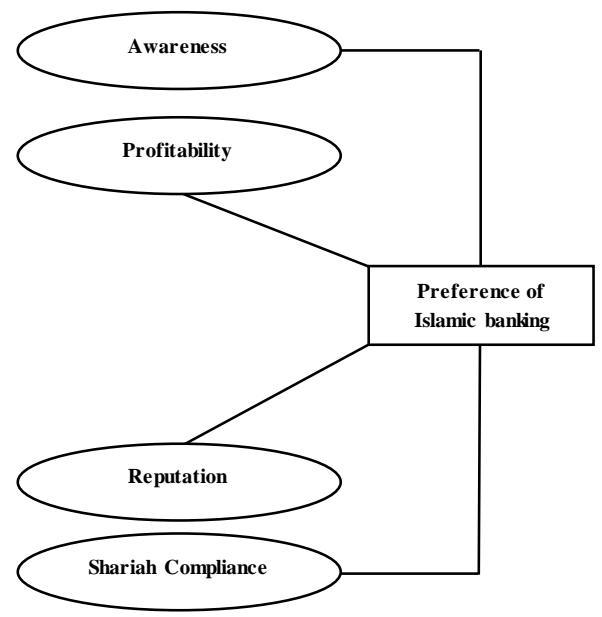

\begin{tabular}{|l|c|c|c|c|}
\hline \multicolumn{5}{|c|}{ Model Summary } \\
\hline Model & $\mathrm{R}$ & $\begin{array}{c}\text { R } \\
\text { Squar } \\
\mathrm{e}\end{array}$ & $\begin{array}{c}\text { Adjusted R } \\
\text { Square }\end{array}$ & $\begin{array}{c}\text { Std. Error of } \\
\text { the Estimate }\end{array}$ \\
\hline 1 & $\begin{array}{r}0.738 \\
\mathrm{a}\end{array}$ & 0.545 & 0.520 & .62076 \\
\hline $\begin{array}{l}\text { a. Predictors: (Constant), Shariah compliance, } \\
\text { Reputation, Awareness, Profitability, Customer } \\
\text { Satisfaction and Service Quality }\end{array}$ \\
\hline
\end{tabular}

\begin{tabular}{|l|c|c|c|c|}
\hline & \multicolumn{2}{|c|}{$\begin{array}{c}\text { Standardiz } \\
\text { ed } \\
\text { Coefficien } \\
\text { ts }\end{array}$} & \\
\cline { 2 - 4 } Model & $\mathrm{B}$ & $\begin{array}{c}\text { Std. } \\
\text { Error }\end{array}$ & Beta & Sig. \\
\hline (Constant) & -.660 & .348 & .061 \\
\hline Awareness & .461 & .092 & .384 & .000 \\
\hline Profitability & .488 & .134 & .333 & .000 \\
\hline Reputation & -.016 & .129 & -.009 & .903 \\
\hline $\begin{array}{l}\text { Shariah } \\
\text { compliance }\end{array}$ & .267 & .090 & .225 & .004 \\
\hline $\begin{array}{l}\text { Customer } \\
\text { Satisfaction } \\
\text { and service } \\
\text { quality }\end{array}$ & .095 & .089 & .089 & .288 \\
\hline \begin{tabular}{l} 
a. Dependent Variable: preference \\
\hline
\end{tabular} & & & & \\
\hline
\end{tabular}

The Regression Analysis shows Awareness, profitability, Shariah Compliance have positive significant relation with preference to Islamic banking.
VI. RESEARCH DESIGN AND METHODOLOGY

This research was carried out by applying exploratory research design. The research was quantitative in nature. The major objective of this study is to find out that why the preference of Islamic banks in Pakistan has increased over the time.

The research design used to accomplish this result is correlation research design and the tool used to conduct this research is questionnaire. The questionnaire was designed on a Likert scale that is the respondent has 5 options to choose from that is 1: Strongly Agree, 2: Agree, 3: Neutral, 4: Disagree, 5: Strongly Disagree. The questionnaire was distributed to 100 respondents the target sample size was of 150 but due to uncertainty and other complications some questionnaires weren't distributed. Out of the 100 respondents the full $100 \%$ replied. The ratio of female respondents to male respondents was relatively very low.

SPSS tools were used to obtain the results from the data received. The tests that were used to obtain the results are Measures of Central Tendency, Correlation Analysis and Regression Analysis.

\section{DISCUSSION AND CONCLUSION}

This research was carried out by applying exploratory research design. The research was quantitative in nature. The major objective of this study was to find out that why the preference of Islamic banks in Pakistan has increased over the time.

The research design used to accomplish this result is correlation research design and the tool used to conduct this research is questionnaire. The questionnaire was designed on a Likert scale. The questionnaire was distributed to 100 respondents the target sample size was of 150 but due to uncertainty and other complications some questionnaires weren't distributed. Out of the 100 respondents the full $100 \%$ replied. The ratio of female respondents to male respondents was relatively very low.

The collection of data was completed on the 14th of May, after the collection of data SPSS tools were used to obtain the results from the data received.

The cross tabulation shows that preference having positive relationship with awareness, profitability, Shariah Compliance and customer satisfaction and service Quality. Awareness having perfect positive relationship with preference, profitability, Shariah compliance and customer satisfaction and service quality. Profitability having perfect positive relationship with awareness, preference, reputation, Shariah compliance and customer satisfaction and service quality. Reputation has relationship with awareness, preference and Shariah compliance, and Shariah compliance has positive relationship with awareness. The Analysis of independent variable i.e. Awareness, profitability, Shariah Compliance 
with dependent variable i.e. preference to Is lamic banking depict positive relationship.

\section{REFERENCES}

[1] M. S. Moin, "A comparative study on performance if Islamic banking and conventional banking is Pakistan," 2008.

[2] A.-K. a. o. Thorsten Beck, "Study by the World Bank management team on Islamic VS conventional banking: Business model, Efficiency and Stability.," 2010.

[3] Worldbank, "The World Islamic banking Competitiveness report 2011-2012," 2012.

[4] A. Hossein, "Islamic Finance, Risk Sharing and International Financial Stability," http://yalejournal.org/article_post/islamic-financerisk-sharing-and-international-financial-stability/ on May 30, 2018, 2012.

[5] Awan, "A study on comparison of Islamic and Conventional banking in Pakistan.," 2009.

[6] I. N. U. E. \&. W. H. Masruki R., "Study on the performance of Malaysian established Islamic banks vs. conventional banks," Journal of business and policy research, vol. vol. 6. 2., 2011.

[7] H. Loghod, "Study on Do Islamic banks perform better than conventional banks?" Evidence from GCC countries, 2005.

[8] J. \&. K. Kuehn, "A study on conventional VS Islamic finance: Student Knowledge and perception in the UAE," International Journal of Islamic Financial Services Vol. 5. 4, 2007.

[9] R. K. Qureshi A. H. Hussain Z, "A study on the comparison between Islamic and Conventional banking sectors of Pakistan.," Information management and Business review., 2012.

[10] B. S. C. a. M. H. Liu, "Study on Islamic banking: Interest free of Interest based," Pacific basin finance journal 17, 2006.

[11] M. Hanif, "A study on Islamic Housing Finance critical analysis and comparison with conventional mortgage," Middle eastern finance and economics, 2010.

[12] U. S. A. a. M. N. Mohammed Azhar Sheikh, "A study on Islamic VS conventional banks in Pakistan.," 2010.

[13] A. W. Dusuki, "The ideal of Islamic banking survey of stake holders," Review of Islamic economics, vol. 11, 2007.

[14] M. Iqbal, "A study on Islamic banking and conventional banking in the nineties," Islamic Economic Studies vol. 8 no. 2, 2001.

[15] K. A. Saeed, "Islamic banking in Pakistan: A review of conventional and Islamic banking.," 2nd international conference on Business Management, n.d.

[16] A. R. a. A. Rahman, " Study on Islamic banking and finance: Between ideals and realities.," Journal of Economics and management., 2007.

[17] M. H. a. Jemma Dredi, "Comparative study on the effects of global crisis of Islamic banks and conventional banks," IMF working paper, 2010.

[18] H. Muhammad, "Differences and similarities in Is lamic and conventional banking," 2011.

[19] M. W. R. a. M. R. K. Syed Farhan Shah, "Research on Islamic banking controversies and challenges," Journal of contemporary research in business, 2012. Firmin H. Aikpo, Miriac Dimitri S. Ahouanse, Lucien Agbandji, Patrick A. Edorh, Christophe S. Houssou (2017). Assessment of contamination of soil by pesticides in Djidja's cotton area in Benin. International Journal of Advanced Engineering Research and Science (ISSN: 2349-6495(P) | 24561908(O)),4(7),

001-005. http://dx.doi.org/10.22161/ijaers.4.7.1

[20] Perfect, T. J., \& Schwartz, B. L. (Eds.) (2002). Applied metacognition Retrieved from http://www.questia.com/read/107598848

[21] Myers, D. G. (2007). Psychology (1stCanadian ed.). New York, NY: Worth.

[22] Cognition. (2008). In Oxford reference online premium dictionary. Retrieved from http://www.oxfordreference.com

[23] Blue, L. (2008, March 12). Is our happiness preordained? [Online exclusive]. Time. Retrieved from http://www.time.com/time/health

[24] J. Clerk Maxwell, A Treatise on Electricity and Magnetism, 3rd ed., vol. 2. Oxford: Clarendon, 1892, pp.68-73.

[25] I. S. Jacobs and C. P. Bean, "Fine particles, thin films and exchange anisotropy," in Magnetism, vol. III, G. T. Rado and H. Suhl, Eds. New York: Academic, 1963, pp. 271-350.

[26] K. Elissa, "Title of paper if known," unpublished.

[27] R. Nicole, "Title of paper with only first word capitalized," J. Name Stand. Abbrev., in press. 